Craenen H., Van Ranst E., Tack F.M.G., Verloo M.G., 2000. Calculation and mapping of critical loads of sulphur and nitrogen in Flanders, Belgium. The Science of the Total Environment 254, 5564.

The original publication is available at http://www.elsevier.com/

\title{
Calculation and mapping of critical loads of sulphur and nitrogen in Flanders, Belgium
}

\author{
Hilde Craenen ${ }^{\mathrm{a}}$, Eric Van Ranst ${ }^{\mathrm{a}}$, Filip M. G. Tack ${ }^{\mathrm{b}^{*}}$, Marc G. Verloo ${ }^{\mathrm{b}}$ \\ ${ }^{a}$ Laboratorium voor Bodemkunde, Universiteit Gent, Krijgslaan 281 (S8), 9000 Gent \\ ${ }^{b}$ Laboratorium voor Analytische Chemie en Toegepaste Ecochemie, Universiteit Gent, Coupure \\ Links 653, 9000 Gent \\ ${ }^{*}$ Corresponding author
}

\section{Corresponding author:}

Filip M.G. Tack

Laboratorium voor Analytische Chemie en Toegepaste Ecochemie

Universiteit Gent

Coupure Links 653

9000 Gent

Tel: +3292645993

Fax: +3292646232

e-mail: Filip.Tack@rug.ac.be 



\title{
Calculation and mapping of critical loads of sulphur and nitrogen in Flanders, Belgium
}

\author{
Hilde Craenen ${ }^{\mathrm{a}}$, Eric Van Ranst ${ }^{\mathrm{a}}$, Filip M. G. Tack ${ }^{\mathrm{b}^{*}}$, Marc G. Verloo $^{\mathrm{b}}$ \\ ${ }^{a}$ Laboratorium voor Bodemkunde, Universiteit Gent, Krijgslaan 281 (S8), 9000 Gent \\ ${ }^{b}$ Laboratorium voor Analytische Chemie en Toegepaste Ecochemie, Universiteit Gent, \\ Coupure Links 653, 9000 Gent \\ ${ }^{*}$ Corresponding author
}

\begin{abstract}
Up to now, critical loads calculations for the Flemish Region were based on European background data of surrounding countries. A first attempt has been made to calculate and map critical loads for forest ecosystems in Flanders using available sitespecific information. Values of current deposition were used to calculate and map exceedances. The lowest critical loads for acidification (697 eq ha ${ }^{-1} \mathrm{yr}$ ) occur in the Campine and the north of Limburg where ecosystems largely consist of coniferous forests on poor sandy soils. The dominance of coniferous forest types in the Campine is also responsible for low critical load values for eutrophication (between 536 and $971 \mathrm{eq}$ $\left.\mathrm{ha}^{-1} \mathrm{yr}^{-1}\right)$. In $75 \%$ of the receptor points that have been considered an exceedance of the critical load for acidification is noted, primarily in areas with high $\mathrm{SO}_{2}$ and $\mathrm{NO}_{\mathrm{x}}$ depositions, such as the north of the provinces East- and West-Flanders and Antwerp. The critical load for eutrophication is exceeded in all points considered. Exceedances are particularly high in coniferous forests in West-Flanders, North-Limburg and in the north of the province of Antwerp, where especially $\mathrm{NH}_{\mathrm{x}}$ depositions amount to high values. Data needed for the calculation of critical loads are still sparse in Flanders, e.g., for: (1) weathering rates of soil minerals; (2) interception and evaporation of forest ecosystems, and (3) uptake of $\mathrm{N}$ and basic cations by vegetation. This supplementary information will contribute to a further refining of the calculated critical loads, which constitute indispensable information in developing an emission abatement policy.
\end{abstract}

Key words: critical loads, acid deposition

\section{Introduction}

Input of air pollutants such as $\mathrm{SO}_{2}, \mathrm{NH}_{\mathrm{x}}$ and $\mathrm{NO}_{\mathrm{x}}$ into forest ecosystems can result in damage to the vegetation both by direct effects on the forest canopy and by indirect soil-mediated processes of acidification and eutrophication in the soil. Direct harm to foliage by pollutants may contribute to the decline of forest vitality in Europe. Besides these direct effects, the disturbance of the nutrient status of forest soils caused by soil acidification and nitrogen accumulation is of major importance (Roberts et al., 1989).

Deposition of $\mathrm{SO}_{2}, \mathrm{NH}_{\mathrm{x}}$ and $\mathrm{NO}_{\mathrm{x}}$ can cause low $\mathrm{pH}$-values and high aluminium concentrations in the soil solution. Exchange of basic cations such as $\mathrm{Ca}^{2+}, \mathrm{Mg}^{2+}, \mathrm{K}^{+}$, and $\mathrm{Na}^{+}$by protons, adsorption of $\mathrm{SO}$ on aluminium and iron hydroxides with the release of $\mathrm{OH}^{-}$into the solution (Johnson, 1984) and acid-base reactions in the soil solution are fast processes which can temporarily counteract acidification. The release 
of basic cations through mineral weathering, on the other hand, is slow but provides a virtually inexhaustible source of buffering capacity (De Vries, 1994). Atmospheric deposition of basic cations is also a long-term source of buffering capacity. Besides their capacity to replace acidity from the sorption complex, basic cations may also improve the nutrient status of the ecosystem by balancing a high nitrogen input.

If rates of acid deposition input exceed the rates of acid neutralizing processes, the soil will acidify. Excessive concentrations of $\mathrm{Al}^{3+}$ and $\mathrm{H}^{+}$in the rooting zone can then exert a toxic effect on the roots of trees and may inhibit basic cation uptake, causing unfavourable ratios of minerals in the plant tissue.

Extra nutrient input into any ecosystem may result in eutrophication. Nitrogen is a growth limiting factor. Initially, extra supply of $\mathrm{N}$ will induce an increase in ecosystem biomass production. Upon further accumulation of inorganic nitrogen, nitrogen tolerant species will gain competitive advantage over less tolerant species and the possibility of nitrogen leaching will increase. An additional effect is the increased susceptibility to frost and fungal diseases related to high leaf nitrogen contents (De Vries, 1988; De Vries, 1990a; De Vries, 1990b).

In the frame of the Geneva Convention on Long Range Transboundary Pollution, ecosystems in Europe are currently being mapped regarding their sensitivity to acidification and eutrophication in co-operation between members of the UN/ECE Task Force on Mapping (Downing et al., 1993). From physical, chemical and geochemical properties of the ecosytem, critical loads are calculated. The critical load is defined as "the highest deposition of a compound that will not cause chemical changes leading to long-term harmful effects on ecosystem structure and function" (Downing et al., 1993). By comparison of the calculated critical loads with actual deposition rates, so-called areas of exceedance can be located.

The critical loads concept is an important instrument in assessing the potential for acidification stress imposed on forest soils by anthropogenic depositions. It is also an indispensable tool to evaluate the efficiency of proposed emission-reduction strategies (Posch et al., 1993) The purpose of determining critical loads is to set the goal for future deposition rates in order to protect the environment. The objective of this study was to perform an initial trial to derive critical loads, using specific information for Flanders (Belgium).

\section{Materials and methods}

\subsection{Computation}

To ensure compatibility between calculated values from different National Focal Centres in Europe, the "Co-ordination Centre for Effects (CCE)" hosted by the RIVM (National Institute of Public Health and Environmental Protection, The Netherlands) proposed a standard protocol for the calculation and mapping of critical loads. The detailed procedure is described in the CCE-Status Report 1993 (Posch et al., 1993). The choice of the computational approach depends on the input data requirements, the complexity of use and the uncertainty tolerated on the calculated value. In this study, the steady state mass balance model was used to derive the critical loads for forest soils only, as the procedure assumes that soils are subjected solely to natural acidification processes. The critical load for acidity, CL(A), considers acidifying effects of sulphur 
and nitrogen deposition. Critical load for nutrient nitrogen, $\mathrm{Cl}_{\text {nut }}(\mathrm{N})$, accounts for both the acidifying and the eutrophying effects of atmospheric deposition of nitrogen. Exceedances of these critical loads are calculated as the difference between the actual loads and the critical loads.

\subsection{Data acquisition}

\subsubsection{Receptor points}

The critical load is related to a receptor, i.e. the ecosystem that is subjected to the harmful effects of atmospheric deposition. Selection of these receptors is the basis of the critical load calculations (Hootsman and van Uffelen, 1991). Receptor points were located on a grid of $5 \mathrm{~km}$ by $5 \mathrm{~km}$ after an overlay of The Flemish Forest Inventory Map (FFIM) on the Soil Association Map of Flanders (Table 1).

The lowest critical load and the highest exceedance within every grid cell was then attributed to the whole cell. By this approach, every ecosystem within a grid cell is protected by this critical load and the worst exceedance situation within every cell is displayed.

\subsubsection{Weathering rates}

Because more specific data on the release of basic cations through mineral weathering are not yet available in Flanders, weathering rates were assessed according to the method proposed by Hettelingh and De Vries (1992). Soil types are classified into four parent material classes and six texture classes. A combination of both classes indicates the weathering class to which the receptor point belongs. To each weathering class, base cation release rates were assigned on the basis of mineralogy, according to Sverdrup and Warfvinge (1988). Weathering rates were calculated for a root zone of 50 $\mathrm{cm}$. This is the rooting depth for trees, commonly assumed in critical load computation.

\subsubsection{Precipitation}

Mean annual precipitation over 10 years (1986-1995) was derived from data of five weather observation stations in Flanders. Each receptor point was assigned the value corresponding to the nearest observation station.

\subsubsection{Interception}

The fraction of the precipitation which is intercepted by coniferous and deciduous trees differs due to the difference in leaf carrying period and leaf type. Values were derived from Hootsmans and Van Uffelen (1991).

\subsubsection{Evapotranspiration}

Evapotransporation in forest stands is difficult to assess as it is influenced by many factors such as leaf area, leaf carrying period, soil moisture content, etc. In Flanders, annual evapotranspiration ranges between 270 and $370 \mathrm{~mm} \mathrm{yr}^{-1}$ (Van Miegroet and Dua, 1985). A value of $320 \mathrm{~mm} \mathrm{yr}^{-1}$ was therefore assumed. 


\subsubsection{Deposition}

Total deposition per component was calculated for a $5 \mathrm{~km} \times 5 \mathrm{~km}$ grid. Filtering factors, that account for the increased capture by forest filtering, were taken from Erisman (1990) for coniferous trees and from Ivens et al.(1988) for deciduous trees.

Atmospheric deposition of basic cations may be of importance in soils where unweathered mineral contents and hence release of basic cations is small. These data are indispensable for the calculation of critical loads. Unfortunately, data on dry and wet basic cation deposition are as yet not available in Flanders. Total deposition of basic cations can be approximated by the total $\mathrm{Ca}^{2+}$ deposition (De Vries, 1994). On the assumption that Flemish conditions are similar to those in The Netherlands, one-year measurements of the mean total $\mathrm{Ca}^{2+}$ deposition near 10 forest plots (Van Den Berghe et al., 1991) were used to estimate deposition of basic cations.

\subsubsection{Uptake by vegetation}

The mean annual uptake of nitrogen and basic cations were estimated from literature data (De Vries, 1990a; De Vries, 1990b). The uptake is strongly related to tree species, forest management and site quality. For coniferous and deciduous wood, mean nitrogen uptakes were estimated to be 300 and 500 eq ha yr, respectively. Hootsmans and Van Uffelen (1991) observed that the uptake of nitrogen and basic cations differs more between forest types than between soil types.

\section{Results and discussion}

\subsection{Deposition}

Deposition patterns are remarkably different between components (Fig. 1 to 3). The dominant source of $\mathrm{SO}_{2}$ and $\mathrm{NO}_{\mathrm{x}}$ is the combustion of fossil fuels. Values are high in urbanised and industrialised areas such as the area between Ghent, Antwerp and Brussels. Intensive animal husbandry, on the other hand, is an important source of $\mathrm{NH}_{\mathrm{x}}$. Indeed, high deposition rates are encountered in the west of Flanders. Total deposition values on the grid cells ranged from 2780 to 4110 eq ha yr (Table 2).

Mean values for total deposition per ecosystem include filter factors to account for the effects of the forest leaves in retaining deposition (Posh et al., 1993). Values were lowest for combinations of calcaric Regisols with deciduous forest. Mixed coniferous forests on orthic Podzols were subject to the highest mean total depositions (Table 3).

Total N-deposition was lowest for coniferous forests on calcaric Regisols. The highest mean total $\mathrm{N}$-depositions were calculated for orthic luvisols under mixed coniferous forest. 


\subsection{Critical loads}

The spatial distributions of the critical loads for acidification and exceedances over the Flemish Region are shown in Fig. 4 and 5. Fig. 6 and 7 show the spatial distribution of respectively the critical loads and the exceedances of the critical loads for nutrient $\mathrm{N}$. The blank grid cells on the maps contain no receptor points. In Table 4 the lowest values of the critical load for acidification (CL(A)) and for nitrogen per receptor type are given.

The highest values of the critical loads for acidification (6053 eq ha yr) were found for calcareous soils under deciduous forest (soil types Jc and Rc, forest type 1). The estimated rate of base cation release from mineral weathering is high in these soils and therefore provides a long term buffering capacity against acidification. Most vulnerable are combinations of coniferous forests and poor sandy soils with a low longterm reserve of neutralising base cations (soil types $\mathrm{Ph}$ and Po, forest types 3 and 4). The lowest critical loads were determined for The Campine and the north of Limburg where the ecosystems largely consist of very sensitive coniferous forests on poor sandy soils.

The critical loads for nitrification $\left(\mathrm{Cl}_{\text {nut }}(\mathrm{N})\right)$ (Fig. 6) were calculated according to the constant denitrification method (Posch et al., 1993). The higher sensitivity of conifers to euthrophication is due to the nitrogen uptake, which is lower than for deciduous tree species. The dominance of coniferous forest types in The Campine is responsible for the low $\mathrm{Cl}_{\text {nut }}(\mathrm{N})$ in this region. Values per receptor type ranged from 536 to 874 eq ha yr (Table 4).

\subsection{Exceedances}

Critical loads for acidification were exceeded for $75 \%$ of the receptor points. The highest exceedances of CL(A), Ex(A) amounted to 6630 eq ha yr in the most sensitive areas. These are mainly found in the northwest of the Flemish Region (Fig. 5). Highest exceedances were calculated for coniferous forests on poor sandy soils situated in areas with high $\mathrm{SO}_{2}$ and $\mathrm{NO}_{\mathrm{x}}$ deposition such as the North of the provinces East- and West-Flanders and Antwerp. One reason for their larger sensitivity is that forest filtering factors are significantly lower for conifers (1) than for deciduous forest (1.8). $\mathrm{NO}_{\mathrm{x}}$ deposition contributes less to the exceedance as the filtering factor of both forest types for this compound is rather low.

Values for exceedances of nitrification varied between 153 and 3501 eq ha yr. The amount of nitrogen disposed and the forest type, in terms of filtering factors, is of great influence. 'Black points', with exceedances above 2000 eq ha yr, are situated mainly in conifer stands in West-Flanders, the north of the provinces Limburg and Antwerp, where high depositions of $\mathrm{NH}_{\mathrm{x}}$ were measured (Fig. 3). Again, the influence of $\mathrm{NO}_{\mathrm{x}}$ deposition is rather limited due to the low forest filtering factors of trees for this compound.

\subsection{Uncertainty}

Uncertainties on critical loads and their exceedances are caused by the application criteria, the available input data and the method applied. Due to the largescale approach, the criteria applied in the method are strongly generalised. To enable the comparison of critical loads on an European scale, it was agreed to use the same criteria 
in national critical load calculations of the National Focal Centers. The uncertainty on the input data is not negligible. All data originated from literature reviews and research performed in the past. If specific data were missing, values from neighbouring countries were used. In the model, several simplifications and assumptions were made. The accuracy of the model depends upon the extent to which these are justified.

\section{Conclusion}

The lowest critical loads for acidification (697 eq ha yr) were calculated for the Campine and the north of Limburg where ecosystems largely consist of very sensitive coniferous forests on low-fertile sandy soils. The dominance of coniferous forest types in the Campine is also responsible for low critical load values for eutrophication (between 536 and $971 \mathrm{eq} \mathrm{ha}^{-1} \mathrm{yr}^{-1}$ ). In $75 \%$ of the receptor points considered an exceedance of the critical load for acidification is noted, primarily in areas with high $\mathrm{SO}_{2}$ and $\mathrm{NO}_{\mathrm{x}}$ depositions, which is the case in the north of the provinces East- and West-Flanders and Antwerp. The critical load for eutrophication is exceeded in all points considered. 'Black points' are situated in coniferous forests in West-Flanders, North-Limburg and in the north of the province of Antwerp, where especially $\mathrm{NH}_{\mathrm{x}}$ depositions amount to high values.

The calculated values indicate trends and provide a good initial estimation of the spatial variability of ecosystem sensitivity to acidification and eutrophication in Flanders. Since political decisions concerning deposition abatement strategies, on a national as well as on a European scale, are based on the accurate regional assessment of critical loads, additional research will be needed to complete available databases and to update computations. In particular, data on (1) mineral weathering rates; (2) interception of rainfall; (3) evapotranspiration, and (4) nutrient uptake by forest vegetation in particular need to be refined and expanded in the future.

\section{References}

De Vries, 1988De Vries W. Critical deposition levels for nitrogen and sulphur on Dutch forest ecosystems. Water Air Soil Pollut 1988; 42:221-239.

De Vries, 1990aDe Vries W. Methodologies for the assessment and mapping of critical acid loads and of the impact of abatement strategies on forest soils in the Netherlands and in Europe. Internal report Winand Staring Centre, Wageningen, The Netherlands, 1990a, 91 pp.

De Vries, 1990bDe Vries W. Philosophy, structure and application methodology of a soil acidification model for the Netherlands. In: Kamari J, editor. Environmental Impact Models to Assess Regional Acidification, Kluwer, Dordrecht, The Netherlands, 1990b, pp. 3-21.

De Vries, 1994De Vries W. Soil response to acid deposition at a different regional scale: field and laboratory data, critical loads and model predictions.

Doctoraatsproefschrift, Universiteit Wageningen, The Netherlands, 1994.

Downing et al., 1993Downing R.J., Hettelingh J.P., de Smet, P.A.M. Introduction, In: Calculation and Mapping of Critical loads in Europe, CCE status report 1993, National Institute of Public Health and Environmental Protection, Bilthoven, The Netherlands, 1993, pp. 1-4. 
Erisman, 1990Erisman JW. Atmospheric deposition of acidifying compounds onto forests in the Netherlands : throughfall measurements compared to deposition estimates from inference. National Institute for Public Health and Environmental Protection, Bilthoven, The Netherlands, 1990, 29 pp.

FAO-UNESCO, 1981FAO-UNESCO. Soil Map of the World, Vol. V : Europe (1: 500,000,000), UNESCO, Paris, France, 1981.

Hettelingh and de Vries, 1992Hettelingh JP, de Vries, W. Mapping Vademecum. Report no.259101002, National Institute of Public Health and Environmental Protection, Bilthoven, The Netherlands, 1992, 39 pp.

Hootsman and van Uffelen, 1991Hootsmans RM, Van Uffelen, JG. Assessment of input data for a simple mass balance model to map critical acid loads for dutch forest soils. Interne mededeling nr. 133, Staring Centrum, Landbouwuniversiteit Wageningen, The Netherlands, 1991, 98 pp.

Ivens et al., 1988Ivens WPMF, Draaijers GPJ, Bos MM, Bleuten W. Dutch forests as pollutant sinks in agricultural areas. A case study in the central part of the Netherlands on the spatial and temporal variability of atmospheric deposition to forests, report 37-09. State University of Utrecht, The Netherlands, 1988, 43pp.

Johnson, 1984Johnson DW. Sulphur cycling in forests. Biogeochem 1984; 1: 29-43.

Posch et al., 1993Posch M, Hettelingh JP, Sverdrup HU, Bull K, De Vries, W. Guidelines for the computation and mapping of critical loads and exceedances of sulphur and nitrogen in Europe. In: Calculation and Mapping of Critical loads in Europe, CCE status report 1993. National Institute of Public Health and Environmental Protection, Bilthoven, The Netherlands, 1993, pp. 25-38.

Roberts et al., 1989Roberts TM, Skeffington RA, Blank LW. Causes of type 1 spruce decline in Europe, Forestry 1989; 62: 179-222.

Sverdrup and Warfvinge, 1988Sverdrup HU, Warfvinge PG. Assessment of critical loads of acid deposition on forest soils. In: Nilsson J, Grennfelt P, editors. Critical loads for sulphur and nitrogen, NORD 1988:97. Nordic Council of Ministers, Copenhagen, Denmark, 1988; pp. 81-129.

Van Den Berghe et al., 1991Van Den Berghe K, Maddelein D, De Vos B., Roskams P. Analyse van de luchtverontreiniging en de gevolgen daarvan op het bosecosysteem. Voorlopige versie eindrapport project nummer 87.60.BL.001.0, Universiteit Gent, Gent, Belgium, 1991.

Van Miegroet and Dua, 1985Van Miegroet M, Dua V. Bossterfte en luchtverontreiniging. Rapport nummer 9, Universiteit Gent, Gent, Belgium, 1985. 
Table 1

Soil and forest types considered and the proportion of the resulting forest-soil combinations (receptor types) in the total number of receptor points

\begin{tabular}{ll}
\hline Soil type (FAO-UNESCO, 1981) & Lithology \\
\hline Rc Calcaric Regosol & recent dune sand \\
Jc Calcaric Fluvisol & recent alluvium \\
Lg Gleyic Luvisol & loess \\
Lo Orthic Luvisol & loess, Tertiary sand and clay \\
Dd Dystric Podzoluvisol & sandy loess, Tertiary green sand \\
Ph Humic Podzol & Pleistocene aeolian sand \\
Po Orthic Podzol & Pleistocene aeolian sand, Tertiary sand
\end{tabular}

\begin{tabular}{|c|c|c|c|}
\hline \multicolumn{2}{|l|}{ Forest type } & \multicolumn{2}{|l|}{ Description } \\
\hline \multicolumn{2}{|c|}{ Deciduous forest } & \multicolumn{2}{|c|}{$<20 \%$ coniferous trees } \\
\hline \multicolumn{2}{|c|}{ Mixed deciduous } & \multicolumn{2}{|c|}{$20-50 \%$ coniferous trees } \\
\hline \multicolumn{2}{|c|}{ Mixed coniferous } & \multicolumn{2}{|c|}{$20-50 \%$ deciduous trees } \\
\hline \multicolumn{2}{|c|}{ Coniferous } & \multicolumn{2}{|c|}{$<20 \%$ deciduous trees } \\
\hline Receptor type & $\%$ & Receptor type & $\%$ \\
\hline Lo-1 & 29.1 & $\mathrm{Po}-1$ & 0.8 \\
\hline $\mathrm{Ph}-4$ & 24.2 & $\mathrm{Lg}-1$ & 0.6 \\
\hline $\mathrm{Ph}-1$ & 14.9 & Po-3 & 0.5 \\
\hline $\mathrm{Dd}-1$ & 10.1 & $\mathrm{Dd}-2$ & 0.3 \\
\hline $\mathrm{Ph}-3$ & 6.1 & Lo-3 & 0.3 \\
\hline Po-4 & 4.1 & Rc-1 & 0.3 \\
\hline $\mathrm{Ph}-2$ & 2.5 & $\mathrm{Jc}-1$ & 0.2 \\
\hline $\mathrm{Dd}-4$ & 2.0 & Lg-3 & 0.2 \\
\hline Lo-4 & 2.0 & $\mathrm{Lg}-4$ & 0.2 \\
\hline $\mathrm{Dd}-3$ & 0.8 & Po-2 & 0.2 \\
\hline Lo-2 & 0.8 & & \\
\hline
\end{tabular}


Table 2

Minimum and maximum total depositions $\left(\mathrm{SO}_{2}+\mathrm{NO}_{\mathrm{x}}+\mathrm{NH}_{\mathrm{x}}\right)$ and $\mathrm{N}$-depositions $\left(\mathrm{NO}_{\mathrm{x}}\right.$ $+\mathrm{NH}_{\mathrm{x}}$ ) per grid cell

\begin{tabular}{lll}
\hline & tot. dep. (eq ha yr) & tot. $\mathrm{N}_{\text {dep. }}$ (eq ha $\left.\mathrm{yr}\right)$ \\
\hline $\min$ & 2780 & 1460 \\
$\max$ & 4110 & 2320 \\
\hline
\end{tabular}


Table 3

Minimum and maximum total depositions $\left(\mathrm{SO}_{2}+\mathrm{NO}_{\mathrm{x}}+\mathrm{NH}_{\mathrm{x}}\right)$ and $\mathrm{N}$-depositions $\left(\mathrm{NO}_{\mathrm{x}}\right.$ $+\mathrm{NH}_{\mathrm{x}}$ ) per ecosystem

\begin{tabular}{lllll}
\hline $\begin{array}{l}\text { tot. dep. } \\
\text { (eq ha yr) }\end{array}$ & type & $\begin{array}{l}\text { tot. } \mathrm{N}_{\text {dep. }} \\
\text { (eq ha yr) }\end{array}$ & type \\
\hline $\min$ & 2613 & $\mathrm{Rc}-1$ & 1253 & Rc-1 \\
$\max$ & 6228 & Po-3 & 2568 & Lo-3 \\
\hline
\end{tabular}


Table 4

Minimum critical load for acidification and nutrient nitrogen per receptor type (eq ha yr)

\begin{tabular}{|c|c|c|c|c|c|c|c|c|}
\hline \multirow[b]{3}{*}{ Soil } & \multicolumn{8}{|c|}{ Forest type } \\
\hline & \multicolumn{2}{|c|}{1} & \multicolumn{2}{|c|}{2} & \multicolumn{2}{|c|}{3} & \multicolumn{2}{|c|}{4} \\
\hline & $\overline{\mathrm{CL}(\mathrm{A})}$ & CLnut(N) & $\overline{\mathrm{CL}(\mathrm{A})}$ & CLnut(N) & $\overline{\mathrm{CL}(\mathrm{A})}$ & CLnut(N) & $\overline{\mathrm{CL}(\mathrm{A})}$ & CLnut(N) \\
\hline $\mathrm{Jc}$ & 6053 & 874 & & & & & & \\
\hline $\mathrm{Rc}$ & 6000 & 812 & & & & & & \\
\hline $\mathrm{Dd}$ & 1512 & 804 & 1573 & 808 & 1248 & 538 & 1248 & 538 \\
\hline $\mathrm{Lg}$ & 1976 & 819 & & & 1627 & 573 & 1627 & 544 \\
\hline Lo & 1512 & 804 & 1678 & 808 & 1377 & 538 & 1336 & 536 \\
\hline $\mathrm{Ph}$ & 1012 & 804 & 1012 & 804 & 697 & 536 & 697 & 536 \\
\hline Po & 1071 & 816 & 1226 & 819 & 836 & 542 & 697 & 536 \\
\hline
\end{tabular}


Fig. captions

Fig. 1. Deposition of $\mathrm{SO}_{2}$

Fig. 2. Deposition of $\mathrm{NO}_{x}$

Fig. 3. Deposition of $\mathrm{NH}_{\mathrm{x}}$

Fig. 4. Critical loads for acidification (CL(A))

Fig. 5. Exceedances of the critical load for acidification (E(A))

Fig. 6. Critical loads for nutrient nitrogen $\left(\mathrm{CL}_{\text {nut }}(\mathrm{N})\right)$

Fig. 7. Exceedances of the critical load for nutrient $\mathrm{N}\left(\mathrm{E}_{\text {nut }}(\mathrm{N})\right)$ 


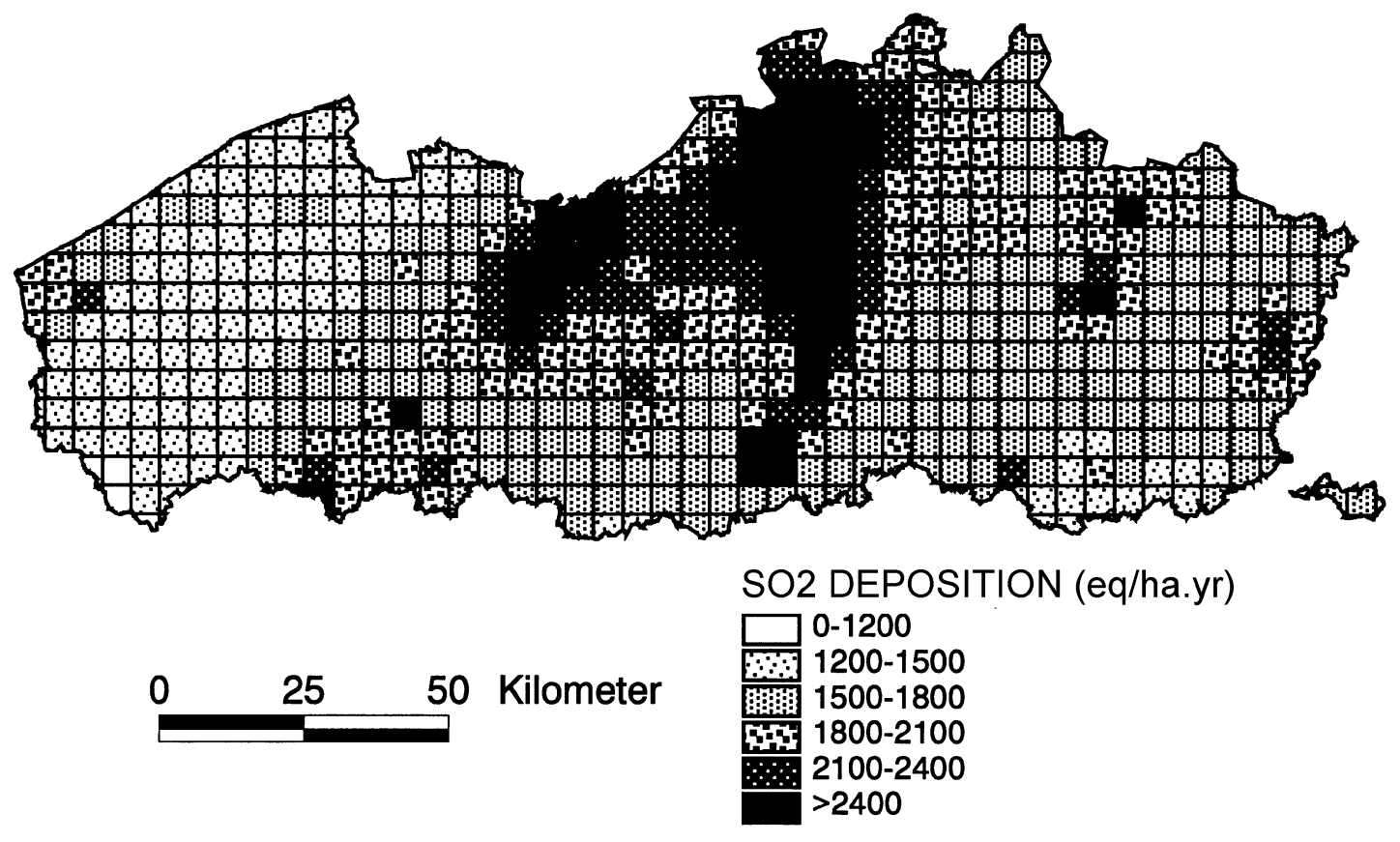

Fig. 1. Deposition of $\mathrm{SO}_{2}$ 


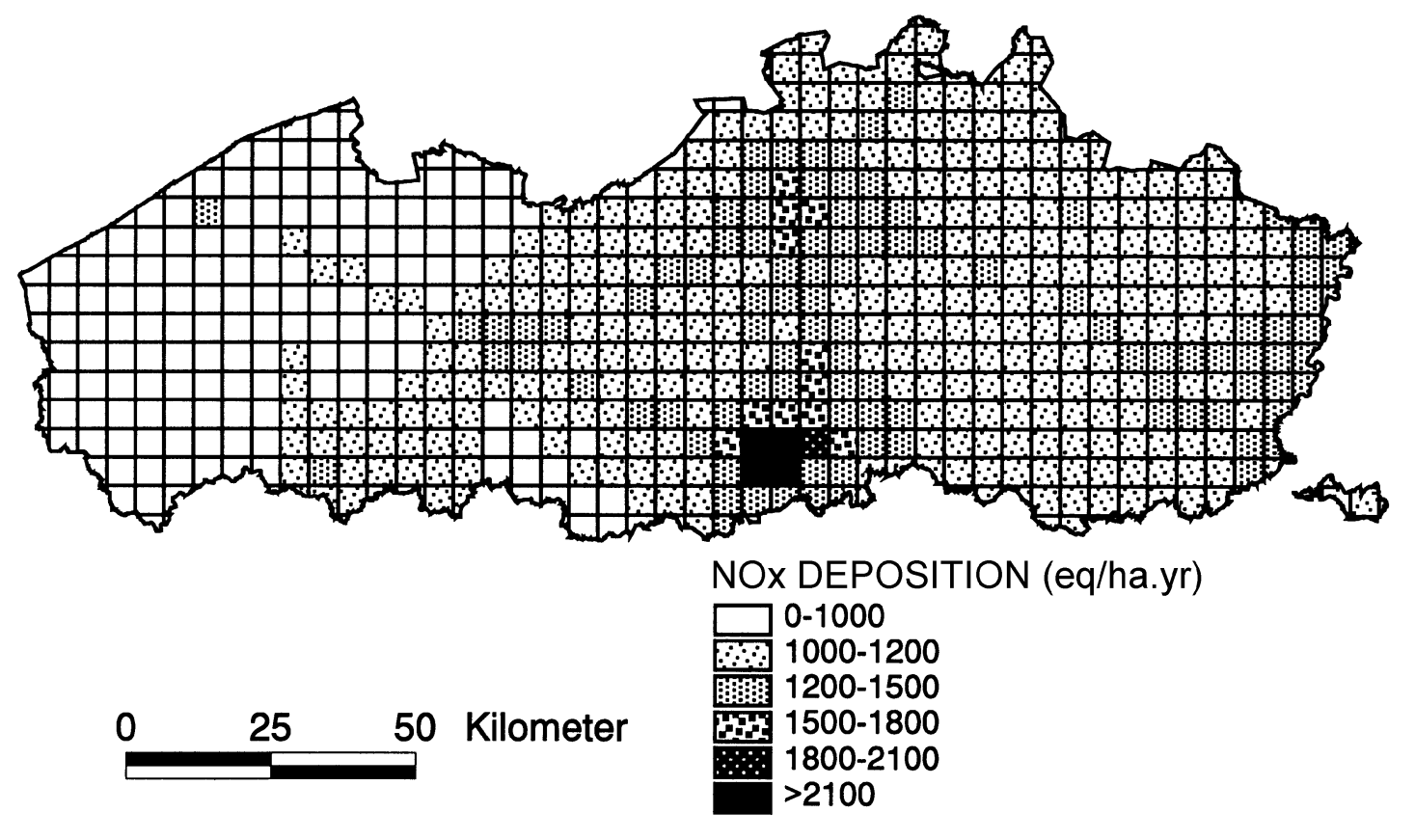

Fig. 2. Deposition of $\mathrm{NO}_{\mathrm{x}}$ 


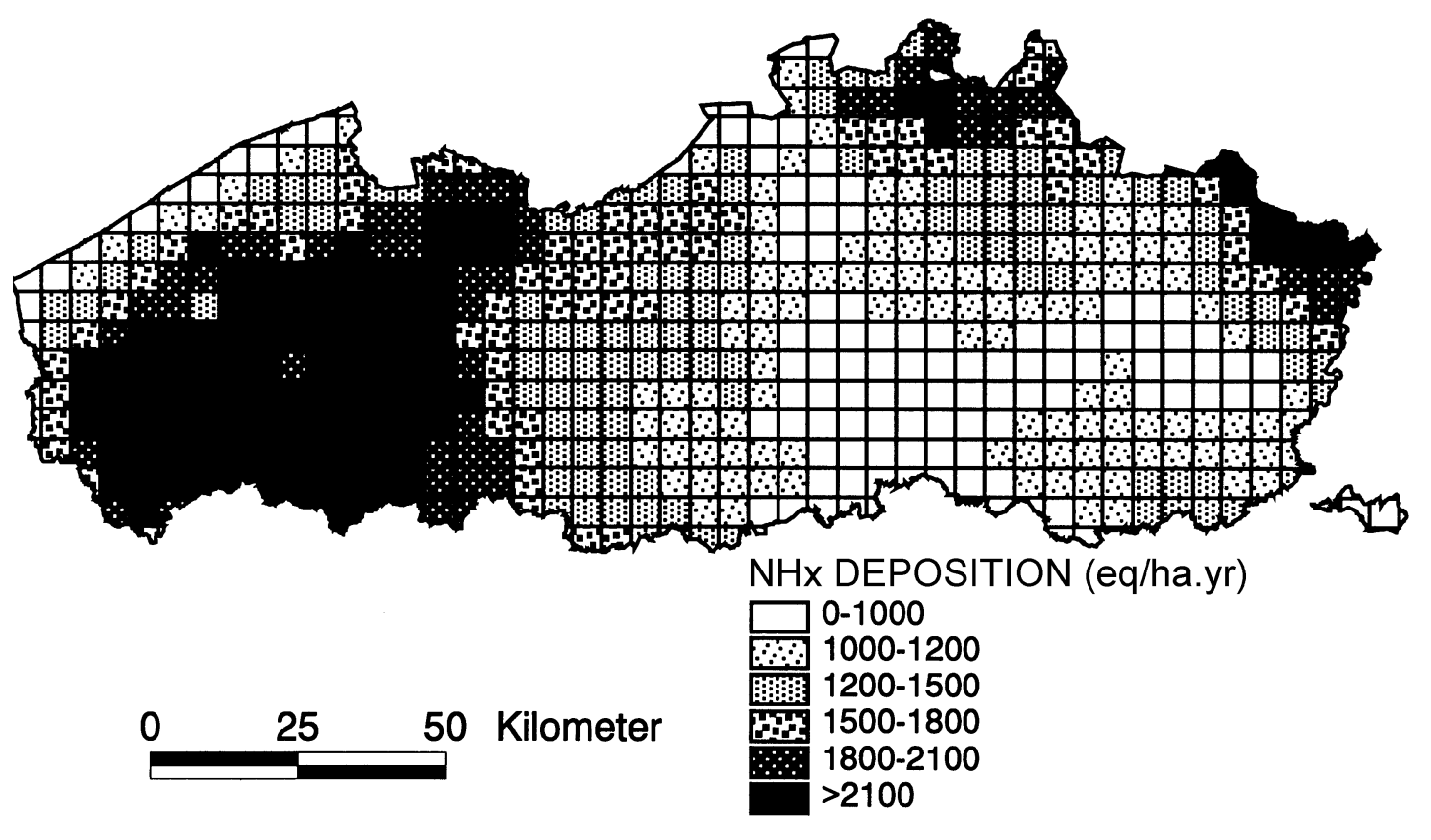

Fig. 3. Deposition of $\mathrm{NH}_{\mathrm{x}}$ 


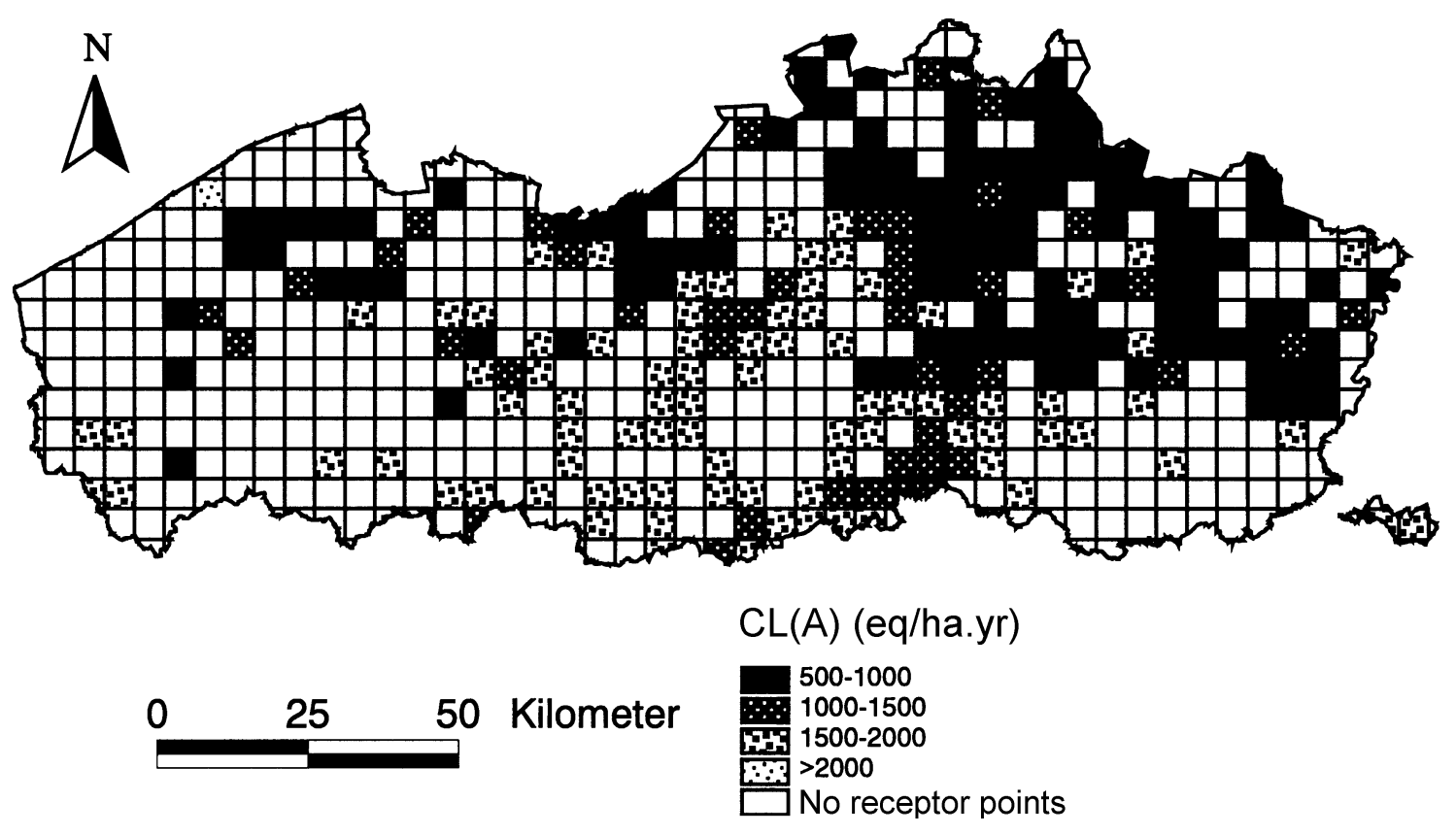

Fig. 4. Critical loads for acidification (CL(A)) 


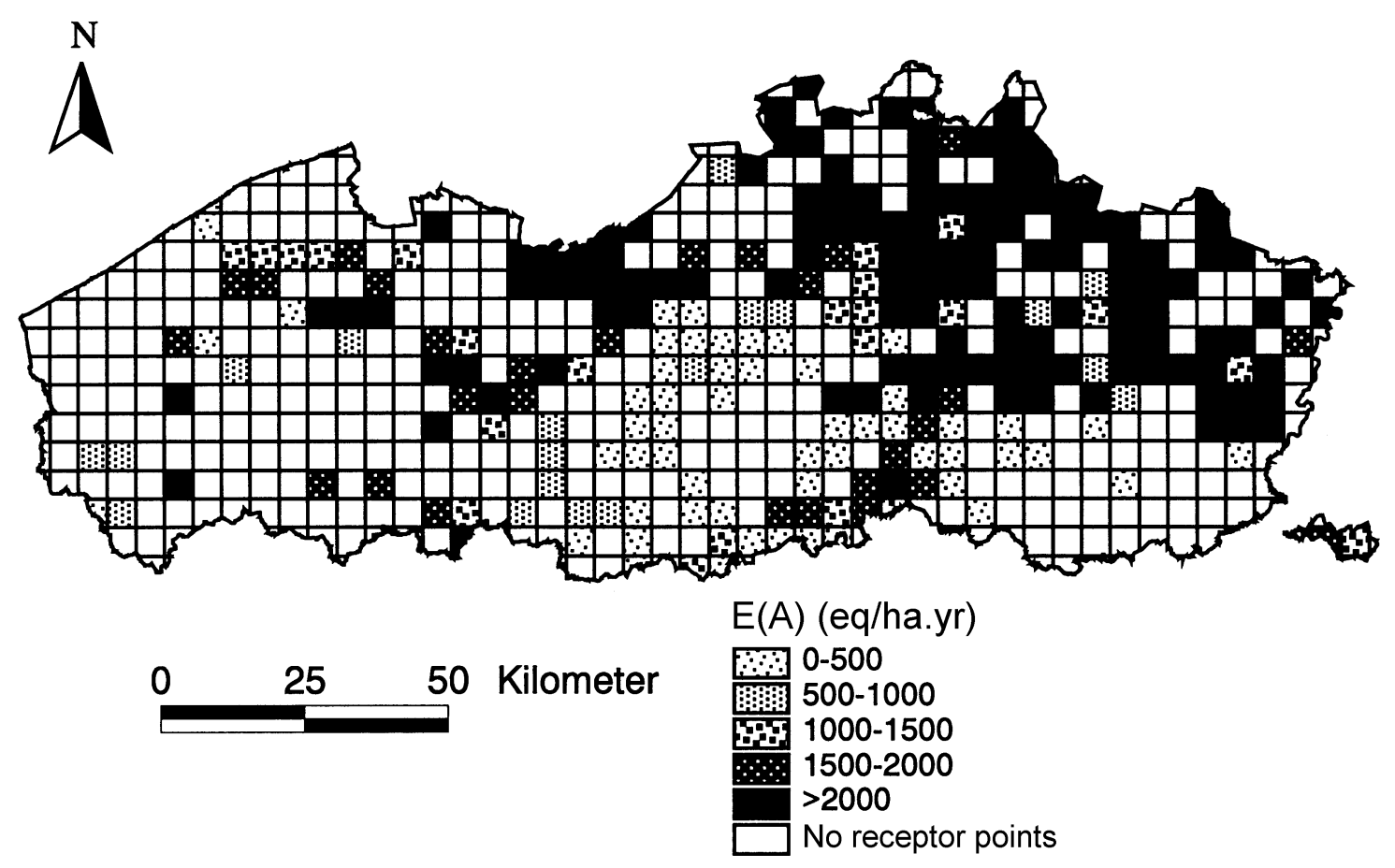

Fig. 5. Exceedances of the critical load for acidification (E(A)) 


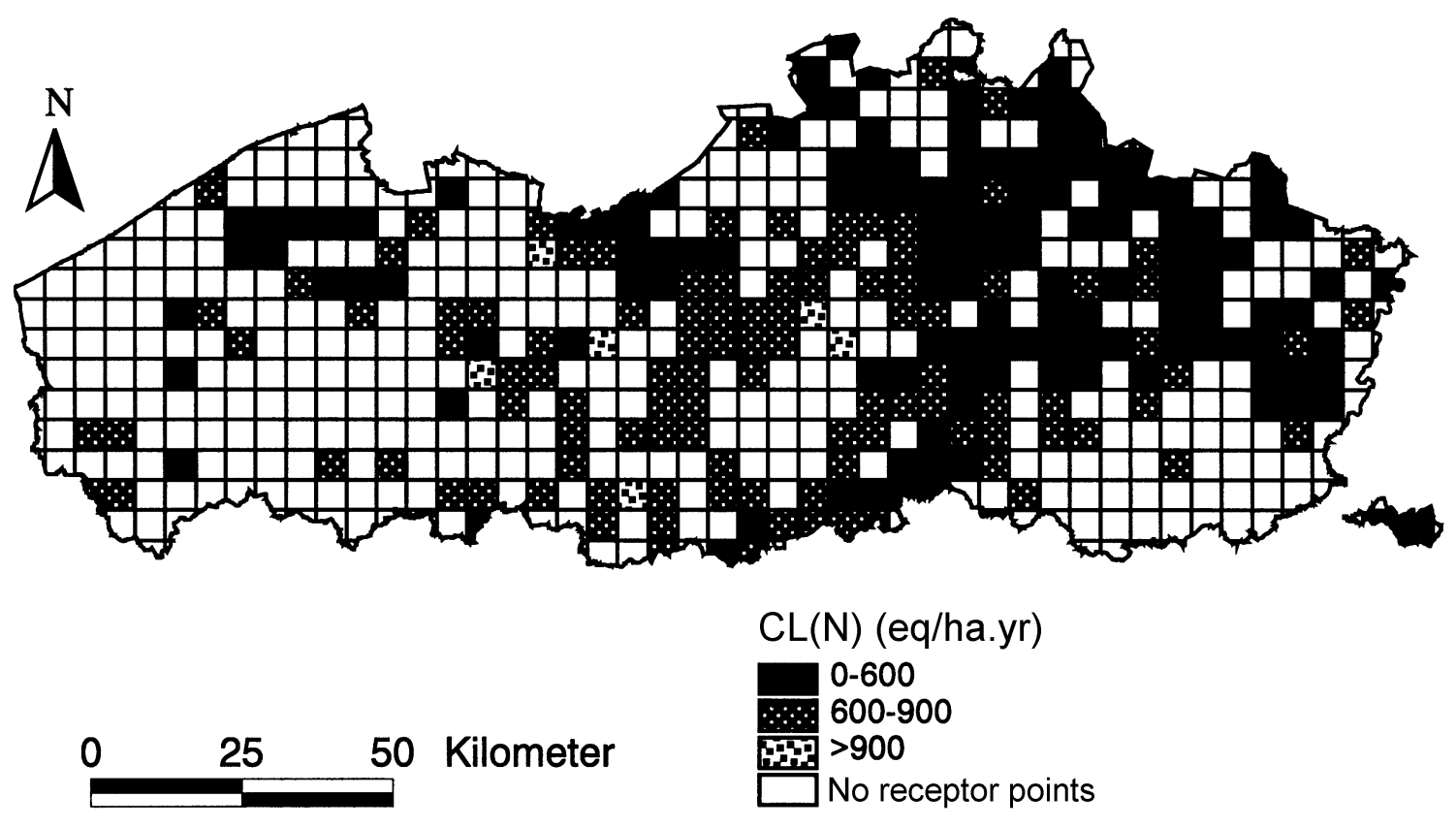

Fig. 6. Critical loads for nutrient nitrogen $\left(\mathrm{CL}_{\text {nut }}(\mathrm{N})\right)$ 


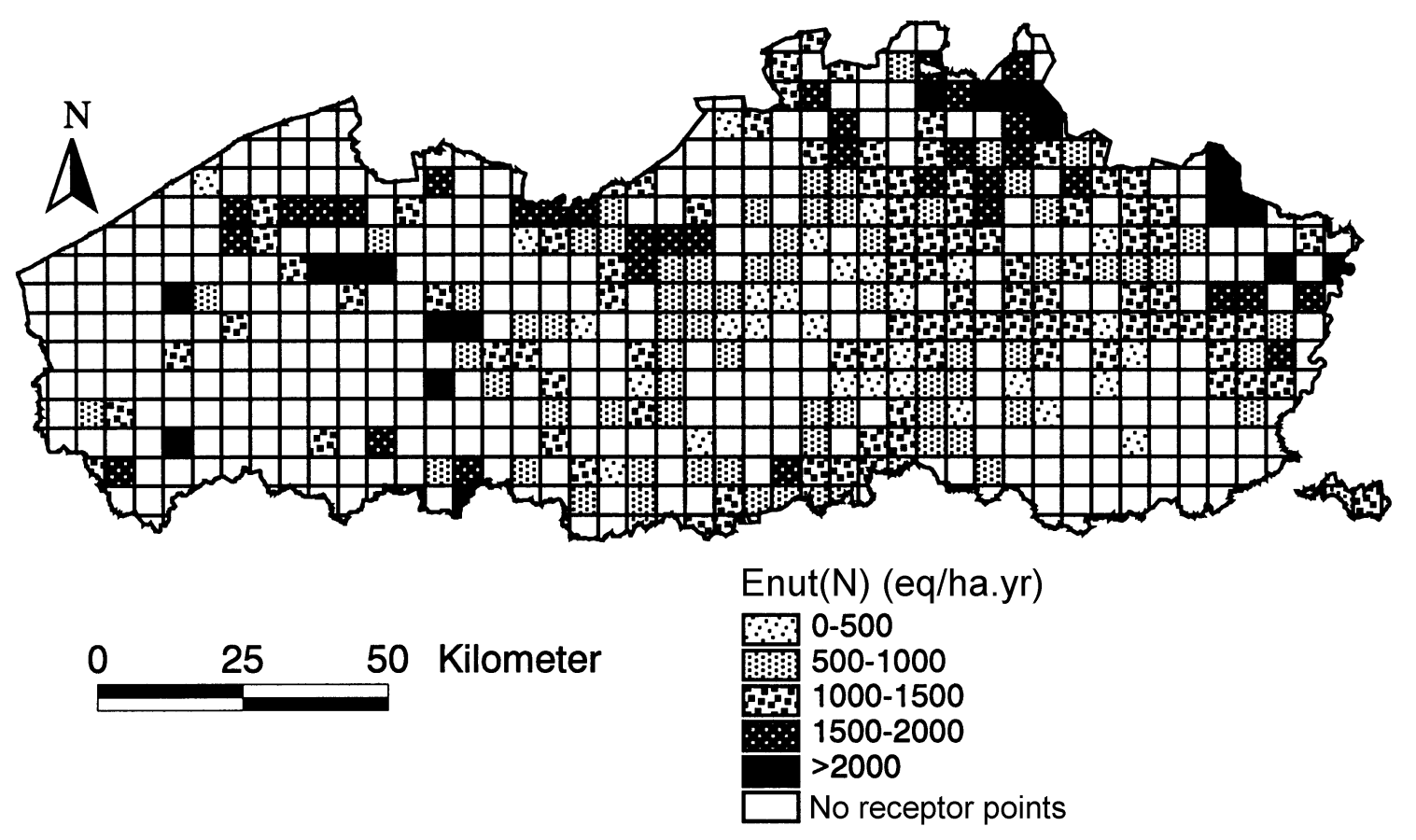

Fig. 7. Exceedances of the critical load for nutrient $N\left(E_{\text {nut }}(N)\right)$ 